\title{
Variation in the size of the osp $A$-containing linear plasmid, but not the linear chromosome, among the three Borrelia species associated with Lyme disease
}

\author{
D. Scott Samuels, ${ }^{*}$ Richard T. Marconi and Claude F. Garon \\ Laboratory of Vectors and Pathogens, Rocky Mountain Laboratories, National Institute of Allergy and Infectious \\ Diseases, Hamilton, Montana 59840, USA
}

(Received 31 December 1992; revised 6 April 1993; accepted 21 May 1993)

\begin{abstract}
The aetiological agents of Lyme disease form a phylogenetically heterogeneous group, composed of three species, Borrelia burgdorferi, Borrelia garinii, and group VS461. We have compared the sizes of the linear plasmid that carries the genes encoding the major outer-surface proteins OspA and OspB as well as the size and structure of the chromosome among the Lyme disease spirochaetes. We have found differences in the sizes of the osp $A$ containing plasmids, but not the linear chromosomes among the three species. The osp $A$-containing plasmid size of $50 \mathrm{~kb}$ in B. burgdorferi isolates is significantly smaller than the size of $55 \mathrm{~kb}$ in B. garinii isolates and $56 \mathrm{~kb}$ in group VS461 isolates. The chromosome was found to be linear in all three Borrelia species, but not significantly different in size.
\end{abstract}

\section{Introduction}

Lyme disease was first described as an outbreak of arthritis in Old Lyme, Connecticut, and nearby communities (Steere et al., 1977). The infection presents a variety of clinical manifestations and is also found in Europe, Asia and Australia (Steere, 1989). The causative agent of Lyme disease was first isolated from its tick vector (Burgdorfer et al., 1982) and then from human patients (Steere et al., 1983; Benach et al., 1983). It is a eubacterium, Borrelia burgdorferi (Johnson et al., 1984), in the spirochaete phylum (Woese, 1987; Paster et al., 1991). Isolates of B. burgdorferi were found to represent more than a single species by several criteria, including 16S RNA sequence (Adam et al., 1991; Marconi \& Garon, 1992a,b), DNA-DNA hybridization (Postic et al., 1990; Baranton et al., 1992), multilocus enzyme electrophoresis (Boerlin et al., 1992), restriction fragment length polymorphisms (Postic et al., 1990; StålhammarCarlemalm et al., 1990; Adam et al., 1991; Marconi \& Garon, 1992a, $c$; Baranton et al., 1992) and arbitrarily primed polymerase chain reaction (Welsh et al., 1992). The species designation $B$. burgdorferi has been amended to delineate a group of North American and European isolates previously referred to as $B$. burgdorferi sensu

*Author for correspondence. Tel. +14063639224; fax

+1 406363 9204; e-mail scott@rml.niaid.nih.gov.

Abbreviation: TAFE, transverse alternating-field electrophoresis. stricto (Baranton et al., 1992; List No. 43, 1992), whilst a new species designation, $B$. garinii, delineates a group of European and Asian isolates previously referred to as group 20047 (Baranton et al., 1992; List No. 43, 1992). A third species (Marconi \& Garon, 1992b), composed of European and Asian isolates, is currently referred to as group VS461 (Baranton et al., 1992). These three species represent three of the four genomic groups based on restriction fragment length polymorphisms of the $f a$, HSP60 and HSP70 genes (Wallich et al., 1992). The three species can be differentiated by reactivity in Western blots with monoclonal antibodies (Jonsson et al., 1992; Baranton et al., 1992), in slot blots with 16S rRNAdirected probes (Marconi et al., 1992) and in the polymerase chain reaction with $16 \mathrm{~S}$ rDNA-directed primer sets (Marconi \& Garon, 1992c). Another set of polymerase chain reaction primers can differentiate $B$. burgdorferi from the other two species (Rosa et al., 1991).

$B$. burgdorferi has an unusual genome composed of a linear chromosome of about $950 \mathrm{~kb}$ (Ferdows \& Barbour, 1989; Baril et al., 1989; Davidson et al., 1992; Casjens \& Huang, 1993) and variable numbers of linear and circular plasmids that range in size from about 5 to $60 \mathrm{~kb}$ (Hyde \& Johnson, 1984; Barbour \& Garon, 1987; Barbour, 1988; Simpson et al., 1990; Samuels \& Garon, 1993). The linear and circular plasmids have copy numbers of about one per chromosome (Hinnebusch \& Barbour, 1992; Casjens \& Huang, 1993). Some of these plasmids are lost during in vitro cultivation (Schwan et 
al., 1988; Barbour, 1988; Norris et al., 1992). The linear plasmids have covalently closed hairpin ends (Barbour \& Garon, 1987) with structures and sequences similar to those of African swine fever virus telomeres (Hinnebusch \& Barbour, 1991). Only four genes have been mapped currently to plasmids; the remainder are on the chromosome (Old et al., 1992; Casjens \& Huang, 1993). The genes for the major outer-surface proteins OspA and OspB are on a $49 \mathrm{~kb}$ linear plasmid in B31 (Barbour \& Garon, 1987) and a slightly larger plasmid in ACAI and R-IP90 (Jonsson et al., 1992). The gene for OspD is on a $38 \mathrm{~kb}$ linear plasmid in B31 that is often lost upon in vitro cultivation (Norris et al., 1992). The gene for OspC, a major immunodominant protein, is on a $26 \mathrm{~kb}$ circular plasmid in all three Lyme disease species (Marconi et al., 1993a) and therefore represents the first Borrelia gene mapped to a circular DNA molecule.

Previously, heterogeneity in the size of the osp Acontaining plasmid has been demonstrated (Barbour, 1988; Stålhammar-Carlemalm et al., 1990; Jonsson et al., 1992; Rosa et al., 1992). This linear plasmid is found in virtually all Lyme disease spirochaete isolates. In the current study, we systematically addressed whether these differences in plasmid size correlated with species. In addition, we examined whether there were differences in the size and structure of the chromosome. Our results indicate that the chromosomes are linear and similar in size, but that the osp $A$-containing plasmids differ in size among the three Borrelia species associated with Lyme disease.

\section{Methods}

Bacterial strains and media. A total of 29 isolates of Lyme disease spirochaetes ( 12 B. burgdorferi, 9 B. garinii and 8 group VS461) were used in this study, 25 in the analysis of the $\operatorname{csp} A$-containing plasmid and 17 in the analysis of the chromosome. These isolates have been identified to the species level and described previously (Marconi \& Garon, 1992c; Baranton et al., 1992). Bacteria were grown at $34^{\circ} \mathrm{C}$ in BSK II medium (Barbour, 1984) with $0.56 \%(\mathrm{w} / \mathrm{v})$ gelatin.

Preparation of DNA and agarose gel electrophoresis. For conventional gel electrophoresis, DNA was isolated as described by Barbour et al. (1985), fractionated on $0.2 \%$ agarose gels (SeaKem GTG, FMC Bioproducts) in recirculated $1 \times$ TAE (40 mM-Tris, $20 \mathrm{~mm}$-acetate, $1 \mathrm{~mm}$-EDTA) at $12 \mathrm{~V}\left(0.4 \mathrm{~V} \mathrm{~cm}^{-1}\right)$ for $88 \mathrm{~h}$, and stained with ethidium bromide as described previously (Samuels \& Garon, 1993). For pulsedfield gel electrophoresis, DNA was prepared in agarose plugs essentially as described by Ferdows \& Barbour (1989) except that the final concentration of agarose (Incert, FMC) was $1 \%$. Plugs were stored in 0.5 M-EDTA ( $\mathrm{pH} \mathrm{8.0)}$ at $4^{\circ} \mathrm{C}$ and equilibrated before use in TE* (10 mM-Tris/HCl, $\mathrm{pH} \mathrm{8.0,10} \mathrm{mM-EDTA).} \mathrm{DNA} \mathrm{was} \mathrm{fractionated}$ on $0.8 \%$ agarose gels by transverse alternating-field electrophoresis (TAFE) in $0.25 \times$ TBE (22 mM-Tris, $22 \mathrm{~mm}$-borate, $0.5 \mathrm{~mm}$-EDTA) using a GeneLine II system (Beckman) set at $13^{\circ} \mathrm{C}$. Electrophoresis was at $350 \mathrm{~mA}$ with pulse times of $60,75,90,105$ and $120 \mathrm{~s}$ for $12 \mathrm{~h}$ each $(60 \mathrm{~h}$ total). Molecular mass standards were either $\lambda$ DNA (incubated at $4{ }^{\circ} \mathrm{C}$ to form dimers) and $\lambda$ DNA-Mono Cut Mix (New England Biolabs) or Saccharomyces cerevisiae strain YNN 295 chromosomal DNA (Beckman). Plasmid and chromosome sizes in $\mathrm{kb}$ were determined using an NA2 nucleic acid analyser (BRL) and were the means of three independent electrophoretic assays for each isolate. Molecular size difference between species were calculated by averaging the mean values for individual isolates of a particular species and performing independent $t$-tests, with significance judged at the 0.05 level. Molecular sizes are presented as the mean $(n=5-9$ isolates of each species) \pm SD.

Southern blot analysis. Fractionated DNA was vacuum-blotted onto GeneScreen membranes (DuPont NEN) using a VacuGene system (Pharmacia LKB) and UV-crosslinked using a Stratalinker (Stratagene) according to the manufacturers' instructions. The membrane was probed with a $5^{\prime}$ end-labelled oligonucleotide ( $5^{\prime}$ dGGCTGCTAACATTTTGCTTACATGC $3^{\prime}$ ) which represents nucleotides 46-70 of the coding region of osp A from B. burgdorferi isolate B31 (Bergström et al., 1989). This oligonucleotide probe specifically recognizes the osp $A$ gene from all isolates from each of the three Lyme disease-associated species tested (Marconi et al., 1993b; R. T. Marconi, D. S. Samuels, T. G. Schwan, M. E. Konkel \& C. F. Garon, unpublished data). Hybridization was at $37^{\circ} \mathrm{C}$ as described previously (Marconi et al., 1992). The membranes were washed twice in $2 \times \mathrm{SSC} / 0.1 \% \mathrm{SDS}$ at $37^{\circ} \mathrm{C}$ and once in $0.1 \times \mathrm{SSC} / 0.1 \% \mathrm{SDS}$ at $37^{\circ} \mathrm{C}$, and exposed to XAR film (Kodak) with intensifying screens at $-70^{\circ} \mathrm{C}$.

\section{Results}

Species variation in the size of the osp A-containing plasmid

The size of the ospA-containing linear DNA molecule, the largest of the plasmids in most isolates, was determined by constant-field electrophoresis in $0.2 \%$ agarose gels (a representative gel is shown in Fig. 1a), which have a linear range of separation from about $10 \mathrm{~kb}$ to over $60 \mathrm{~kb}$ (Sambrook et al., 1989). The osp $A$ gene was identified by Southern blotting with an oligonucleotide probe to a conserved region (a representative blot is shown in Fig. $1 b$ ). The size was determined by regression from the size of intact and restricted $\lambda$ DNA markers on at least two electrophoretic assays. We found that the osp $A$-containing plasmid from $B$. burgdorferi isolates (1352, 20004, Illinois 1, 3028, IP2A, 25015, B31, CA3 and Sh-2-82) had a mean size of $50 \cdot 2 \pm 0.8 \mathrm{~kb}$. The osp $A-$ containing plasmid from $B$. garinii isolates (G1, G25, VS102, R-IP90, FRG, 20047, 153, G2 and UO1) was larger with a greater variance (mean size of $55.5 \pm 1.8 \mathrm{~kb}$ ). The osp $A$-containing plasmid from group VS461 isolates (R-IP3, R-IP21, VS461, PGau, J1, UMO1 and ECM1) had the largest mean size and variance $(56 \cdot 4 \pm 2.3 \mathrm{~kb})$ of the Lyme disease spirochaetes. The size of the plasmid from $B$. burgdorferi isolates was significantly smaller than that from $B$. garinii isolates $\left(P=2 \times 10^{-8}\right)$ and group VS461 isolates $\left(P=1 \times 10^{-8}\right)$. However, the sizes of the plasmids from the latter two species were statistically indistinguishable $(P=0 \cdot 4)$. The mean sizes determined for each species are consistent with those previously reported for individual isolates. Direct contour length measurements by electron microscopy have 


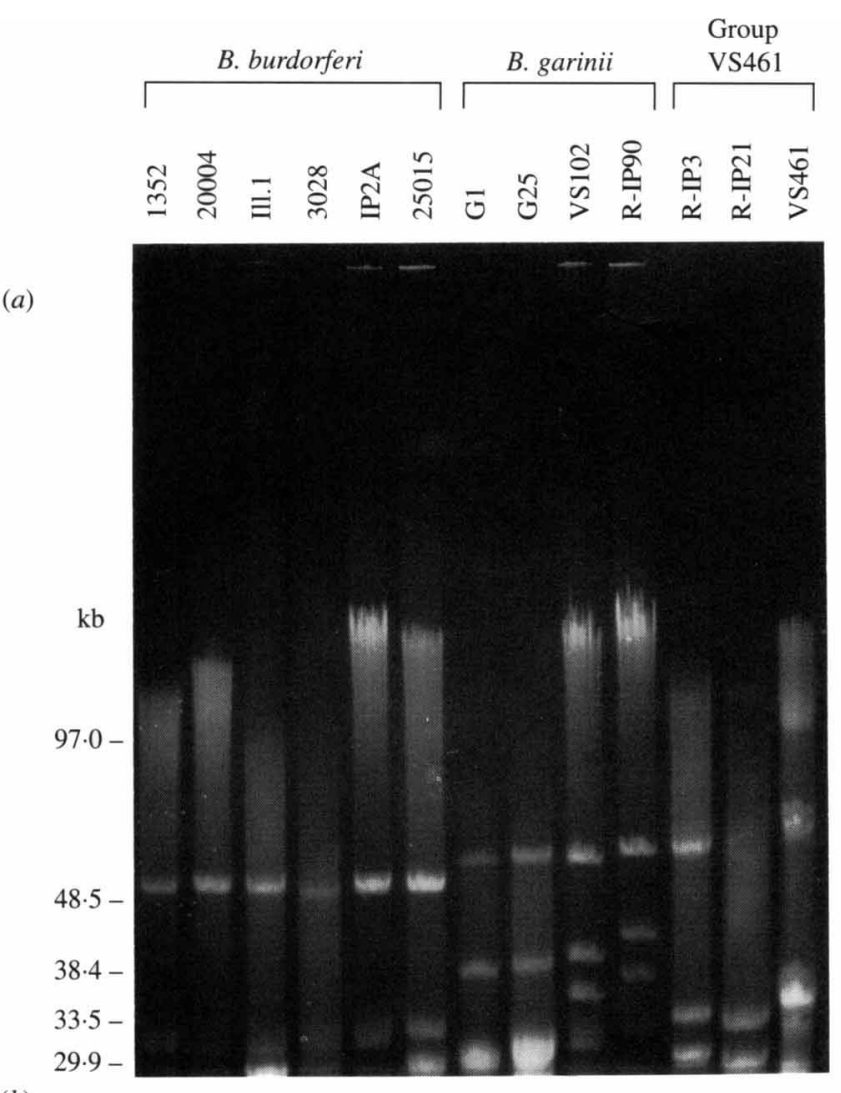

(b)

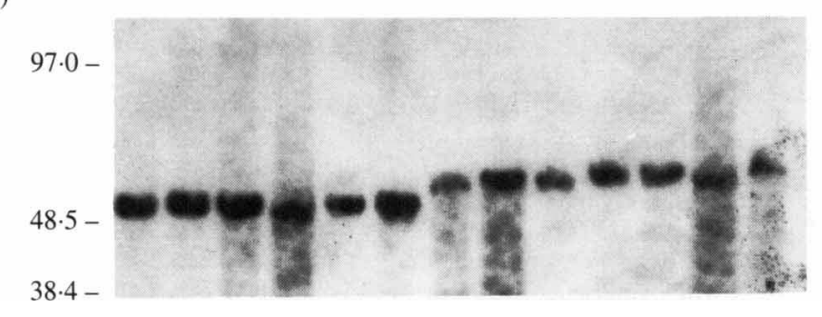

Fig. 1. Size of the osp $A$-containing plasmid among the Borrelia species associated with Lyme disease. (a) Ethidium bromide-stained $0.2 \%$ agarose gel of DNA from representative isolates of $B$. burgdorferi (1352, 20004, Illinois 1, 3028, IP2A and 25015), B. garinii (G1, G25, VS102 and R-IP90), and group VS461 (R-IP3, R-IP21 and VS461). Electrophoresis conditions were designed to maximize separation in the size range of the $\operatorname{ssp} A$-containing plasmid and therefore some smaller plasmids were not retained on the gel. (b) Southern blot of the gel shown in $(a)$ probed with an oligonucleotide from the osp $A$ gene.

revealed the size of the largest linear plasmid of $B$. burgdorferi isolate B31 to be $49 \mathrm{~kb}$ (Barbour \& Garon, 1987) or $53 \mathrm{~kb}$ (Stålhammar-Carlemalm et al., 1990), and those of the $B$. garinii isolates NE83 and NE2 to be 58 and $57 \mathrm{~kb}$, respectively (Stålhammar-Carlemalm et $a l .$, 1990). Pulsed-field gel electrophoresis has indicated that the $o s p$ operon-containing plasmid of $B$. burgdorferi isolate $\mathrm{B} 31$ is smaller than those of the $B$. garinii isolate R-IP90 and the group VS461 isolate ACAI (Jonsson et $a l ., 1992$ ), and that the osp operon-containing plasmid of the $B$. garinii isolate $\mathrm{G} 2$ is larger than those of the $B$.

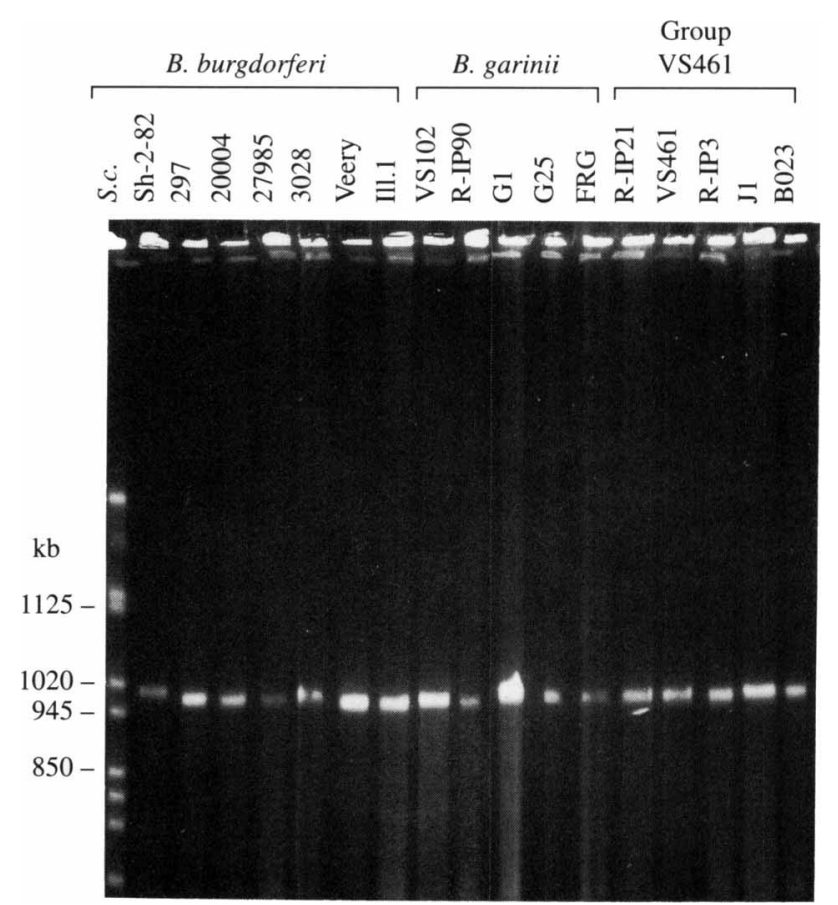

Fig. 2. Size and structure of the chromosome among the Borrelia species associated with Lyme disease. Ethidium bromide-stained TAFE gel $(0.8 \%$ agarose) of DNA from representative isolates of $\boldsymbol{B}$. burgdorferi (Sh-2-82, 297, 20004, 27985, 3028, Veery and Illinois 1), $B$. garinii (VS102, R-IP90, G1, G25 and FRG), and group VS461 (R-IP21, VS461, R-IP3, J1 and BO23). TAFE conditions were designed to maximize separation in the size range of the chromosome and therefore linear plasmids were not retained on the gel. S.c. indicates linear yeast chromosome molecular mass markers.

burgdorferi isolates B31 and Sh-2-82 (Rosa et al., 1992). Conventional gel electrophoresis has also shown that the approximately $50 \mathrm{~kb}$ (linear) plasmid of several $B$. burgdorferi isolates is smaller than those from $B$. garinii and group VS461 isolates (Barbour, 1988). Some isolates contain a linear plasmid larger than the $\operatorname{sp} A$-containing plasmid (about $63 \mathrm{~kb}$ in the case of VS461) (Fig. 1 and data not shown).

The size of the linear chromosome is constant across species

The chromosome has been shown to be a linear molecule of about $950 \mathrm{~kb}$ in $B$. burgdorferi by its ability to enter pulsed-field electrophoresis gels (Ferdows \& Barbour, 1989; Baril et al., 1989) and its linear physical map (Davidson et al., 1992; Casjens \& Huang, 1993). By the criterion of entry into the gel, the chromosomes from all Lyme disease spirochaetes examined were linear (a representative gel is shown in Fig. 2), as were the chromosomes from the non-Lyme disease spirochaetes $B$. hermsii, B. parkeri, B. turicatae, B. coriaceae and $B$. anserina (Marconi et al., 1993c). The size of the 
chromosome was interpolated by regression from the size of intact yeast chromosomes on three electrophoretic assays. The chromosome from $B$. burgdorferi isolates (Sh-2-82, 297, 20004, 27985, 3028, Veery and Illinois 1) had a mean size of $964 \pm 11 \mathrm{~kb}$. The chromosome from $B$. garinii isolates (R-IP90, G1, G25, FRG and VS102) had a smaller mean size and less variance $(957 \pm 4 \mathrm{~kb})$. The chromosome from group VS461 isolates (R-IP21, VS461, R-IP3, J1 and BO23) was also smaller and had less variance than the $B$. burgdorferi chromosome, with a mean size of $958 \pm 2 \mathrm{~kb}$. Although the size of the chromosome from the $B$. burgdorfer $i$ isolates was slightly larger and more variable than the chromosomes from $B$. garinii and group VS461 isolates, the difference was statistically indistinguishable $(P=0-2)$. These values for chromosome size are similar to, but slightly larger than, those determined by clamped homogeneous electrode field (CHEF) pulsed-field gel electrophoresis and physical mapping, and they are consistent in that the $B$. burgdorferi chromosome was found to be slightly larger and more variable in size than those of the other two species (S. Casjens, personal communication).

\section{Discussion}

We have found that the three recently defined Borrelia species associated with Lyme disease have differences in the sizes of their $\operatorname{csp} A$-containing plasmids but not their linear chromosomes. The $o s p A$-containing plasmid from $B$. burgdorferi was statistically smaller than the corresponding DNA molecules in the other species. However, the size differences are not great enough to be of diagnostic value (with the possible exception of differentiating $B$. burgdorferi isolates from $B$. garinii and group VS461 isolates on the basis of osp $A$-containing plasmid size). Most isolates have unique plasmid profiles (Fig. $1 a$ and data not shown), as demonstrated previously (Barbour, 1988; Schwan et al., 1988; Stålhammar-Carlemalm et al., 1990; Jonsson et al., 1992; Norton Hughes et al., 1992). Plasmid profiles were not, however, correlated with the phylogenetically established species (Fig. $1 a$ and data not shown). The role of the $63 \mathrm{~kb}$ linear plasmid in VS461 and other isolates should be pursued, as this plasmid represents approximately $5 \%$ of the genome.

We initially attempted to size the osp $A$-containing plasmids by pulsed-field gel electrophoresis (TAFE) and found values larger than those obtained with constantfield gel electrophoresis (data not shown). This incongruity in molecular size was reported by Norton Hughes et al. (1992) and may also affect the chromosome size determination. We believe that conventional gel electrophoresis yields a more accurate size for plasmids because the values are consistent with those obtained by direct electron microscopy contour length measurement (Barbour \& Garon, 1987; Stålhammar-Carlemalm et al., 1990). Perhaps the partial retardation of linear plasmid migration in pulsed-field gels is caused by the covalently closed ends (Barbour \& Garon, 1987), in a similar fashion to the retardation of circular plasmid migration (Ferdows \& Barbour, 1989; Marconi et al., 1993c; W. O. Granath, L. Lubke \& C. F. Garon, unpublished data).

We thank Joe Hinnebusch and Kit Tilly for their thoughtful and critical review of the manuscript; John Anderson, Guy Baranton, Alan Barbour, Steve Barthold, Russ Johnson, Alan MacDonald, Jeff Nelson, Olivier Peter, Daniele Postic, Julie Rawlings, Patti Rosa, Tom Schwan and Allen Steere for generously providing isolates; the members of LVP and the RML Lyme group for valuable discussions; Lori Lubke for electron microscopy; Sherwood Casjens and Bill Granath for advice on PFGE; Dara Newman and Diana Pilson for useful discussions regarding statistical analysis; Sherwood Casjens for communicating results prior to publication; and Bob Evans and Gary Hettrick for figure preparation.

\section{References}

Adam, T., Gassmann, G. S., Rasiah, C. \& Göbel, U. B. (1991). Phenotypic and genotype analysis of Borrelia burgdorferi isolates from various sources. Infection and Immunity 59, 2579-2585.

Baranton, G., Postic, D., Saint Girons, I., Boerlin, P., Piffaretti, J.-C., Assous, M. \& Grimont, P. A. D. (1992). Delineation of Borrelia burgdorferi sensu stricto, Borrelia garinii sp. nov., and group VS461 associated with Lyme borreliosis. International Journal of Systematic Bacteriology 42, 378-383.

BARBOUR, A. G. (1984). Isolation and cultivation of Lyme disease spirochetes. Yale Journal of Biology and Medicine 57, 521-525.

Barbour, A. G. (1988). Plasmid analysis of Borrelia burgdorferi, the Lyme disease agent. Journal of Clinical Microbiology 26, 475-478.

BARBOUR, A. G. \& GARON, C. F. (1987). Linear plasmids of the bacterium Borrelia burgdorferi have covalently closed ends. Science 237, 409-411.

Barbour, A. G., Heiland, R. A. \& Howe, T. R. (1985). Heterogeneity of major proteins in Lyme disease borreliae: a molecular analysis of North American and European isolates. Journal of Infectious Diseases 152, 478-484.

Baril, C., Richaud, C., Baranton, G. \& Saint Girons, I. (1989). Linear chromosome of Borrelia burgdorferi. Research in Microbiology 140, 507-516.

Benach, J. L., Bosler, E. M., Hanrahan, J. P., Coleman, J. L., Bast, T. F., Habicht, G. S., Cameron, D. J., Ziegler, J. L., Barbour, A. G., Burgdorfer, W., Edelman, R. \& Kaslow, R. A. (1983). Spirochetes isolates from the blood of two patients with Lyme disease. New England Journal of Medicine 308, 740-742.

Bergström, S., Bundoc, V. G. \& Barbour, A. G. (1989). Molecular analysis of the linear plasmid encoded major surface proteins, OspA and $\mathrm{OspB}$, of the Lyme disease spirochete Borrelia burgdorferi. Molecular Microbiology 3, 479-486.

Boerlin, P., Peter, O., Bretz, A.-G., Postic, D., Baranton, G. \& PiffaretTI, J.-C. (1992). Population genetic analysis of Borrelia burgdorferi isolates by multilocus enzyme electrophoresis. Infection and Immunity 60, 1677-1683.

Burgdorfer, W., Barbour, A. G., Hayes, S. F., Benach, J. L., GrunwaldT, E. \& Davis, J. P. (1982). Lyme disease - a tick-borne spirochetosis? Science 216, 1317-1319.

Casjens, S. \& HuANG, W. M. (1993). Linear chromosomal physical and genetic map of Borrelia burgdorferi, the Lyme disease agent. Molecular Microbiology 8, 967-980.

Davidson, B. E., MacDougall, J. \& SaInt Girons, I. (1992). Physical map of the linear chromosome of the bacterium Borrelia burgdorferi 212, a causative agent of Lyme disease, and localization of rRNA genes. Journal of Bacteriology 174, 3766-3774. 
Ferdows, M. S. \& Barbour, A. G. (1989). Megabase-sized linear DNA in the bacterium Borrelia burgdorferi, the Lyme disease agent. Proceedings of the National Academy of Sciences of the United States of America 86, 5969-5973.

HINNEBUSCH, J. \& BARBOUR, A. G. (1991). Linear plasmids of Borrelia burgdorferi have a telomeric structure and sequence similar to those of a eukaryotic virus. Journal of Bacteriology 173, 7233-7239.

HinNEBUSCH, J. \& BARBouR, A. G. (1992). Linear- and circularplasmid copy numbers in Borrelia burgdorferi. Journal of Bacteriology 174, 5251-5257.

Hyde, F. W. \& Johnson, R. C. (1984). Genetic relationship of Lyme disease spirochetes to Borrelia, Treponema and Leptospira spp. Journal of Clinical Microbiology 20, 151-154.

Johnson, R. C., Schmid, G. P., Hyde, F. W., Steigerwalt, A. G. \& BRENNER, D. J. (1984). Borrelia burgdorferi sp. nov.: etiologic agent of Lyme disease. International Journal of Systematic Bacteriology 34, 496-497.

Jonsson, M., Noppa, L., Barbour, A. G. \& Bergström, S. (1992). Heterogeneity of outer membrane proteins in Borrelia burgdorferi: comparison of osp operons of three isolates of different geographic origins. Infection and Immunity 60, 1845-1853.

LisT No. 43 (1992). Validation of the publication of new names and new combinations previously effectively published outside the IJSB. International Journal of Systematic Bacteriology 42, 656-657.

MARCONI, R. T. \& GARON, C. F. (1992a). Phylogenetic analysis of the genus Borrelia: a comparison of North American and European isolates of $B$. burgdorferi. Journal of Bacteriology 174, 241-244.

MarCONI, R. T. \& Garon, C. F. (1992b). Identification of a third genomic group of Borrelia burgdorferi through signature nucleotide analysis and 16S rRNA sequence determination. Journal of General Microbiology 138, 533-536.

MarCONI, R. T. \& Garon, C. F. (1992c). Development of polymerase chain reaction primer sets for diagnosis of Lyme disease and for species-specific identification of Lyme disease isolates by $16 \mathrm{~S}$ rRNA signature nucleotide analysis. Journal of Clinical Microbiology 30, 2830-2834. (1993) Erratum. Journal of Clinical Microbiology 31, 1026.

Marconi, R. T., Lubke, L., Hauglum, W. \& Garon, C. F. (1992). Species-specific identification of and distinction between Borrelia burgdorferi genomic groups by using 16S rRNA-directed oligonucleotide probes. Journal of Clinical Microbiology 30, 628-632.

MarConi, R. T., SAMUEls, D. S. \& Garon, C. F. (1993a). Transcriptional analyses and mapping of the ospC gene in Lyme disease spirochetes. Journal of Bacteriology 175, 926-932.

MaRConi, R. T., Konkel, M. E. \& GARON, C. F. (1993b). Variability of the $\operatorname{ssp} A B$ genes and gene products among species of Lyme disease spirochetes. Infection and Immunity 61, 2611-2617.

Marconi, R. T., Samuels, D. S., Schwan, T. G. \& Garon, C. F. $(1993 c)$. Identification of a protein in several Borrelia species which is related to OspC of the Lyme disease spirochetes. Journal of Clinical Microbiology 31, 2577-2583.

Norris, S. J., Carter, C. J., Howell, J. K. \& Barbour, A. G. (1992). Low-passage-associated proteins of Borrelia burgdorferi B31 : characterization and molecular cloning of OspD, a surface-exposed, plasmid-encoded lipoprotein. Infection and Immunity 60, 4662-4672.

Norton Hughes, C. A., Kodner, C. B. \& Johnson, R. C. (1992). DNA analysis of Borrelia burgdorferi NCH-1, the first northcentral U.S. human Lyme disease isolate. Journal of Clinical Microbiology 30, 698-703.
Old, I. G., MacDougall, J., Saint Girons, I. \& Davidson, B. E. (1992). Mapping of genes on the linear chromosome of the bacterium Borrelia burgdorferi: possible locations for its origin of replication. FEMS Microbiology Letters 99, 245-250.

Paster, B. J., Dewhirst, F. E., Weisburg, W. G., Tordoff, L. A., Fraser, G. J., Hespell, R. B., Stanton, T. B., Zablen, L., ManDELCO, L. \& WoEse, C. R. (1991). Phylogenetic analysis of the spirochetes. Journal of Bacteriology 173, 6101-6109.

Postic, D., Edlinger, C., Richaud, C., Grimont, F., Dufresne, Y., Perolat, P., Baranton, G. \& Grimont, P. A. D. (1990). Two genomic species in Borrelia burgdorferi. Research in Microbiology 141, 465-475.

Rosa, P. A., Hogan, D. \& Schwan, T. G. (1991). Polymerase chain reaction analyses identify two distinct classes of Borrelia burgdorferi. Journal of Clinical Microbiology 29, 524-532.

Rosa, P. A., Hogan, D. \& Margolis, N. (1992). Molecular analysis of the major outer surface protein locus from a divergent Borrelia burgdorferi isolate from Europe. In Lyme Disease: Molecular and Immunologic Approaches, pp. 95-110. Edited by S. E. Schutzer. Cold Spring Harbor, NY: Cold Spring Harbor Laboratory.

SambrooK, J., Fritsch, E. F. \& Maniatis, T. (1989). Molecular Cloning: A Laboratory Manual, 2nd edn. Cold Spring Harbor, NY: Cold Spring Harbor Laboratory.

Samuels, D. S. \& Garon, C. F. (1993). Coumermycin $A_{1}$ inhibits growth and induces relaxation of supercoiled plasmids in Borrelia burgdorferi, the Lyme disease agent. Antimicrobial Agents and Chemotherapy 37, 46-50.

Schwan, T. G., Burgdorfer, W. \& Garon, C. F. (1988). Changes in infectivity and plasmid profile of the Lyme disease spirochete, Borrelia burgdorferi, as a result of in vitro cultivation. Infection and Immunity 56, 1831-1836.

Simpson, W. J., Garon, C. F. \& Schwan, T. G. (1990). Analysis of supercoiled circular plasmids in infectious and non-infectious Borrelia burgdorferi. Microbial Pathogenesis 8, 109-118.

Stålhammar-Carlemalm, M., Jenny, E., Gern, L., Aeschlimann, A. \& MEYER, J. (1990). Plasmid analysis and restriction fragment length polymorphisms of chromosomal DNA allow a distinction between Borrelia burgdorferi strains. Zentrablatt für Bakteriologie 274, 28-39.

STEERE, A. C. (1989). Medical progress: Lyme disease. New England Journal of Medicine 321, 586-596.

Steere, A. C., Malawista, S. E., Snydman, D. R., Shope, R. E., Andiman, W. A., Ross, M. R. \& Steele, F. M. (1977). Lyme arthritis: an epidemic of oligoarticular arthritis in children and adults in three Connecticut communities. Arthritis and Rheumatism 20, 7-17.

Steere, A. C., Grodzicki, R. L., Kornblatt, A. N., Craft, J. E., Barbour, A. G., BURgdorfer, W., SChmid, G. P., Johnson, E. \& Malawista, S. E. (1983). The spirochetal etiology of Lyme disease. New England Journal of Medicine 308, 733-740.

Wallich, R., Helmes, C., Schaible, U. E., Lobet, Y., Moter, S. E., KrAMER, M. D. \& SimON, M. M. (1992). Evaluation of genetic divergence among Borrelia burgdorferi isolates by use of OspA, fla, HSP60 and HSP70 gene probes. Infection and Immunity 60, 4856-4866.

Welsh, J., Pretzman, C., Postic, D., Saint Girons, I., Baranton, G. \& MCClelland, M. (1992). Genomic fingerprinting by arbitrarily primed polymerase chain reaction resolves Borrelia burgdorferi into three distinct phyletic groups. International Journal of Systematic Bacteriology 42, 370-377.

WOESE, C. R. (1987). Bacterial evolution. Microbiological Reviews 51, 221-271. 